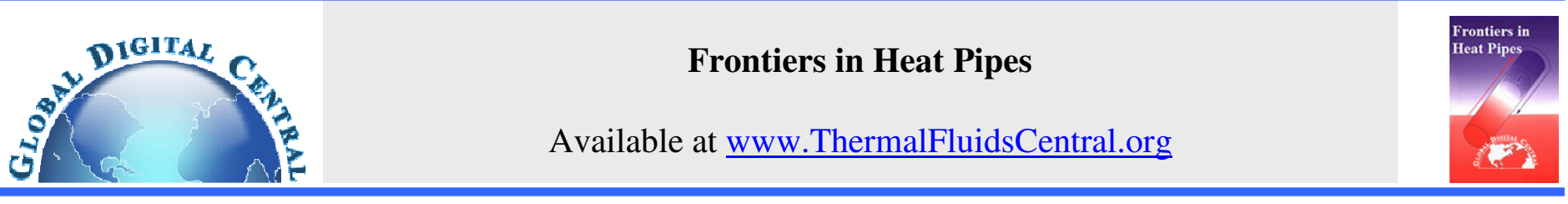

\title{
COLD ENERGY STORAGE SYSTEMS USING HEAT PIPE TECHNOLOGY FOR COOLING DATA CENTERS
}

\author{
Xiao Ping $\mathrm{Wu}^{\mathrm{a},{ }^{*}}$, Masataka Mochizuki ${ }^{\mathrm{a}}$, Koichi Mashiko ${ }^{\mathrm{a}}$, Thang Nguyen ${ }^{\mathrm{a}}$, Tien Nguyen ${ }^{\mathrm{a}}$, \\ Vijit Wuttijumnong ${ }^{\mathrm{a}}$, Gerald Cabusao ${ }^{\mathrm{a}}$, Randeep Singh ${ }^{\mathrm{a}}$, Aliakbar Akbarzadeh ${ }^{\mathrm{b}}$ \\ ${ }^{a} R \& D$ Department, Thermal Technology Division, Fujikura Ltd, Tokyo, 1-5-1, Kiba, Koto-Ku, Tokyo 135-8512, Japan \\ ${ }^{b}$ Energy CARE Group, RMIT University, Melbourne, Australia
}

\begin{abstract}
A novel type of heat pipe application for cold energy storage has been proposed and discussed in this paper. The cold storage system is aiming to save electricity for data center cooling. A typical wickless heat pipe - thermosiphon (thermal-diode heat pipe) will be employed in this application. The thermosiphon cold energy storage systems can be designed into several types that are ice storage, cold water storage and precool heat exchanger. Those systems can be used for co-operating with conventional chiller system for cooling data centers. The heat load used for discussing in this paper is $8800 \mathrm{~kW}$ which represents a large scale data center. The methodology addressed in this paper can be also converted into the middle and small sizes of the data centers. This type of storage system will help to downsize the chiller and decrease its running time that would be able to save significant electricity cost and decrease green house gas emissions from the electricity generation. The proposed systems can be easily connected into the existing conventional systems without major design changes. The analysis in this paper is using Air Freezing Index AFI $>=400{ }^{\circ} \mathrm{C}$-days/year for sizing the heat pipe modules. For the locations where AFI has different value the storage size will be varied accordingly. The paper also addressed a result that an optimum size of cold energy storage system that should be designed at a level to handle $60 \%$ of total yearly heat load of a data center.
\end{abstract}

\section{INTRODUCTION}

The power consumption cost is one of the major operating costs in a data center. Since the power supplied to the data center is ultimately dissipated as heat, a significant fraction of total power consumption will be necessarily used for running cooling system. Kenneth (2006) investigated heat density trends in sever and storage products and charted projection from $2,000 \mathrm{~W} / \mathrm{m} 2$ in the year 1992 increasing up to $60,000 \mathrm{~W} / \mathrm{m} 2$ in the 2010 (Kenneth, 2006).

The cooling power is estimated sharing from $30 \%$ up to $50 \%$ of total power consumption in the data centers. Since the power is still increasing yearly basis, the power consumption and cooling issues have already affected commercial market for server's applications. According to analysis, 3 out of 10 organizations have been impacted by the power consumption to their plan to purchase servers. For example, a data center with $8800 \mathrm{~kW}$ heat load that could consume more than $\$ 4$ million a year which is just the electrical bill for the cooling. This would be a considerable financial issue for an user who is planning to invest this kind of data center. Additionally, power consumption increase is directly relating to the greenhouse-gas emissions as analyzed by the scientists worldwide (Patel et al., 2002; Moore et al.,2004 and Schmidt et al., 2009).

In recent years, the global warming and abnormal weather like heat waves, coastal flooding and glaciers melting have been reported and physically felt by humankind. To save our planet, consequently, investigations on energy conservation for major power consumers such as data centers are becoming an important issue.

In the paper, an innovative method that is applying thermosiphon (thermal-diode heat pipe) to capture cold energy from the ambient during cold weather and stores the cold energy into the ice or water phase has been introduced. The storage system can be used for partially replacing conventional chiller system for the data center cooling to save significant electricity cost.

\section{PRINCIPLE OF OPERATION}

The proposed system utilizes a special type of heat pipe - wickless heat pipe or named thermosiphon as shown in Fig. 1.

A thermosiphon is made from a sealed metal pipe as its container. Unlike conventional heat pipes in which wick structure is built on the internal wall of the pipe, the thermosiphon internal wall has none wick to be built. As well known, the function of the wick is for capillary of liquid from condenser section to evaporator section in the heat pipe and vaporizing the liquid when heat is applied at the heating area (Zhang et al., 2002 and Singh et al., 2009).

Without wick structure, the thermosiphon will not work when the heat is applied at the condenser section when this section is positioned on top of the thermosiphon, specially, when the thermosiphon is vertically located. Thus, alternatively, thermosiphon has an another name that is thermal-diode heat pipe. 
A certain amount working fluid which can vaporize and condense in a proper temperature range will be charged into the pipe. All nocondensed gases inside of the pipe will be fully evacuated. An evaporator section of the thermosiphon is locating at the bottom area of the pipe which is dipped into the media (water) of the storage and a condenser section with fins equipped is locating at the top area of the thermosiphon which will be exposed to the ambient air, as shown in Fig. 1.

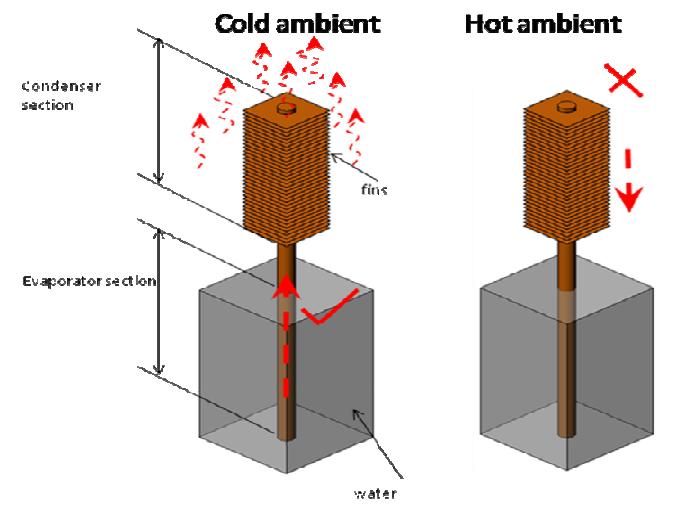

Fig. 1 Thermosiphon diode characteristics

When the media (water) temperature in the storage is higher than ambient temperature or the ambient temperature is lower than water temperature, for example, during a winter season in a cold territory, working fluid in the evaporator will be vaporized and extracting the heat from the high temperature media resulting in media temperature decreasing. The vapor will carry the heat moving up into the condenser section and transfer the heat into fins. The fins will dissipate the heat into the low temperature ambient air. Simultaneously, the vapor in the condenser section will be cooled down and condensed back to liquid phase then returning to the evaporator section by gravity. This thermal cycle will be continuously carried on by means of the evaporationcondensation process when the temperature of the storage media (water) is higher than the ambient temperature. However, when ambient temperature is equal to the storage media's temperature or higher than it, the heat transfer will be automatically stopped since thermal cycle has been broken due to none wick structure being built inside of the pipe.
This is the unique characteristics of the thermosiphon (thermal diode heat pipe). With this one way heat transfer characteristics it can be ensured that the heat will not be transferred in opposite way from ambient to the media (water) during hot weather as shown in right hand side picture in the Fig. 1.

\section{SYSTEM DESCRIPTION}

Figure 2 shows the schematic of the data center cooling system utilizing the proposed heat pipe based cold energy storage. The overall system consists of storage system 1, conventional chiller system 4 and data center server system 5 .

In the storage system 1 , the thermosiphons 2 are installed on top of the storage tank 3. and evaporator sections of the themosiphons will be dipped into the water media in the tank. The working relationship between storage system 1 and chiller system 4 is that storage system 1 will be simply connected with the chiller system 4 via pipes and three way valves. The three way valves can automatically control the water flow rate from storage system merging into the chiller system according to the water temperature variation in the storage tank. For example, during winter time, the water temperature is higher than ambient thus thermosiphons can extract cold energy from the ambient, the three way valve will allow more quantity of the water flow entering the chiller system resulting in that cooling load of chiller decreases, consequently, electricity consumption also decreases. However, during warm season, when ambient temperature becomes higher than certain level of the water temperature, $25{ }^{\circ} \mathrm{C}$ for example, the thermosiphons will automatically stop working and the three way valves will be shut down. The storage system will be isolated from the chiller system and none water flow will be entered into the chiller system from the storage system. The heat load will be fully carried on by the chiller as a conventional system.

It is emphasized that the server system 5, and CPU temperature control will not be affected by the load changes year around from the cold energy storage system due to season variations. The cooling load running through those equipment will be the same as they are running in the conventional chiller systems. The only difference is that power consumption of chiller can be reduced since the storage system is involved.

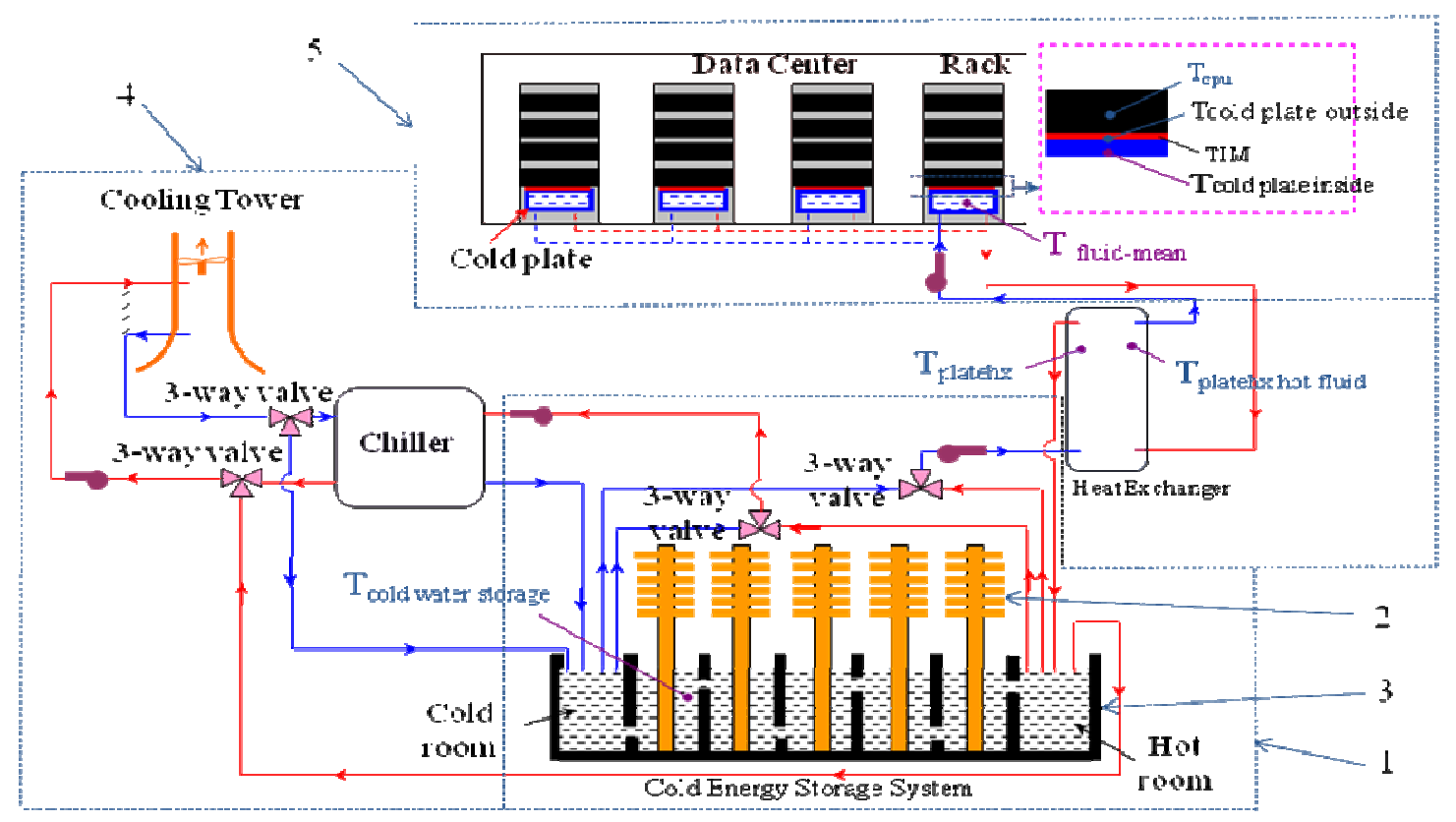

Fig. 2 Cold storage system co-operating with chiller system: cold storage system, 2- thermosiphon, 3- storage tank, 4 - chiller system, 5 - computer system 


\section{THERMAL ANALYSIS}

Fig. 3 shows geometry of the thermosiphon module to be discussed. The thermosiphon tube is made from stainless steel pipe. Fins are made from Aluminum. R134a is filled in the thermosiphon as a working fluid. The length of evaporator section is $3 \mathrm{~m}$ and condenser is $2 \mathrm{~m}$ respectively.

For design of the thermosiphon cold energy storage system, firstly, water calculation temperature in the storage tank is one of the most essential parameters to be determined. This water temperature should be sufficiently lower than CPU surface temperature to be able to cover the temperature rising range that caused by thermal resistances from heat transfer equipment such as heat exchanger (estimated as $15{ }^{\circ} \mathrm{C}$ ), contact thermal resistance such as heat transfer through layer(s) of thermal interface material (TIM) (estimated as $15^{\circ} \mathrm{C}$ ) and heat gained from piping surface during transportation of the water (estimated as $5^{\circ} \mathrm{C}$ ) as well as other unpredicted cold energy loss (estimated as $5^{\circ} \mathrm{C}$ ). Thus the total temperature rise would be $40^{\circ} \mathrm{C}$. Consider the nominally permissible temperature for the CPU surface Tcpu is usually known as $65{ }^{\circ} \mathrm{C}$. The maximum cold water temperature in the storage will be allowed as $65-40=25^{\circ} \mathrm{C}$. In another words, directly and fully using cold water from storage to cool the CPU, the maximum temperature of the water is supposed to be $25{ }^{\circ} \mathrm{C}$. When storage water temperature is higher than $25^{\circ} \mathrm{C}$, the chiller will be fully taking part in the cooling operation and storage water system will be stopped.

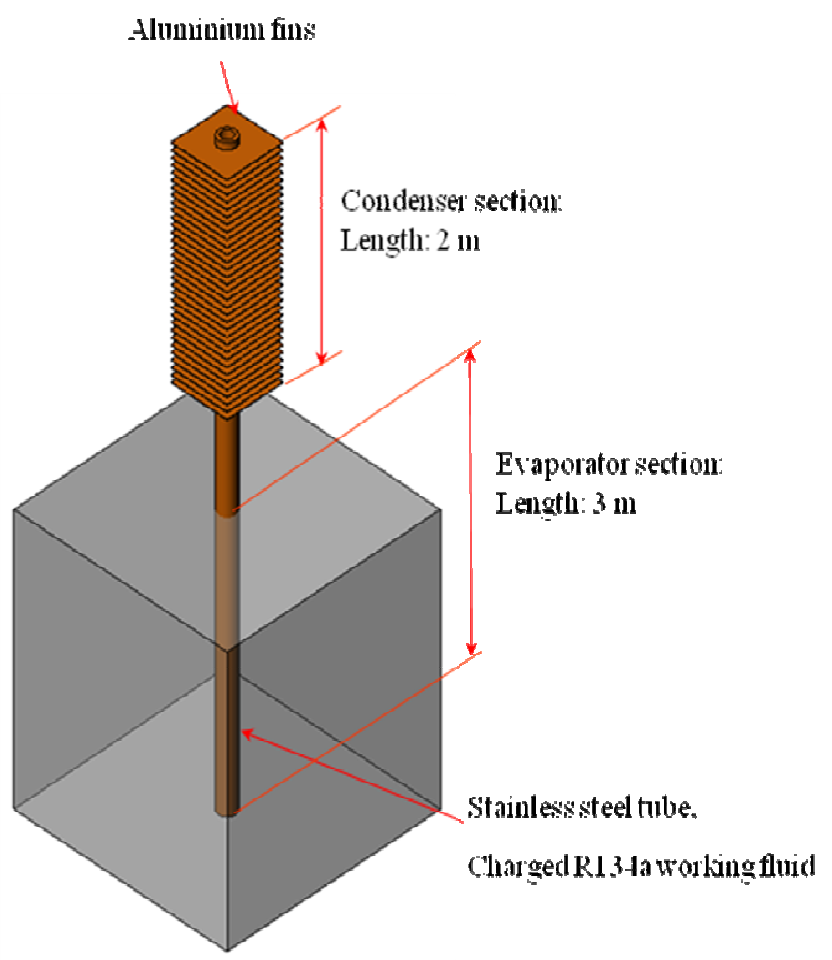

Fig. 3 Geometry of thermosiphon module.

Fig. 4 shows analysis of thermal resistance circuit for thermosiphon module. In the module, since water to thermosipon pipe outer wall is dominated by natural convection, the equation for calculating thermal resistance per unit length for this item is then following:

$R_{o}=\frac{1}{h_{c} A_{e o}}$
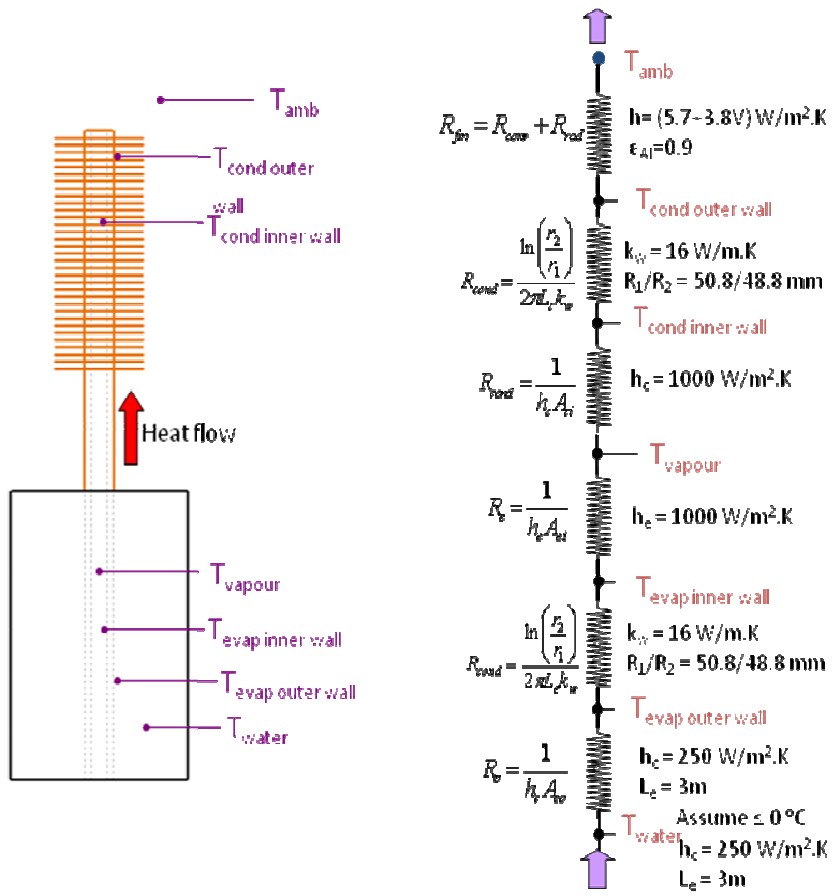

Fig. 4 Thermal resistance circuit from water through thermosiphon to ambient

The thermal resistance through pipe wall at evaporator section per unit length will be:

$R_{\text {cond }}=\frac{\ln \left(\frac{r_{2}}{r_{1}}\right)}{2 \pi L_{e} k_{w}}$

Then per unit length thermal resistance at evaporator section:

$R_{e}=\frac{1}{h_{e} A_{e i}}$

at condenser section internal wall surface:

$$
R_{c o d}=\frac{1}{h_{c} A_{c i}}
$$

through condenser section wall:

$R_{\text {cond }}=\frac{\ln \left(\frac{r_{2}}{r_{1}}\right)}{2 \pi L_{c} k_{w}}$

and finally fins to the ambient:

$$
R_{\text {fin }}=R_{\text {conv }}+R_{\text {rad }}
$$

With the geometries shown in Fig. 3 and parameters shown in Fig. 4, the total thermal resistance through equations (1) to (6) will be obtained as $\mathrm{Rtl}=0.02{ }^{\circ} \mathrm{C} / \mathrm{W}$ for this module.

An experimental test module was built and tested at Aomori where was locating in a northern territory of Japan in 2008 and 2009. For investigating the cold energy capability that can be provided at a local area where the data center will be built, a parameter AFI is necessary to be introduced. AFI is defined as Air Freezing Index which is given by the summation of the degree-days for freezing or thawing condition in 
the area interested. Below equations (7) and (8) are the mathematical expression for AFI modeling:

$\bar{T}=\frac{T_{\min }+T_{\max }}{2}$

where $T_{\min }$ represents minimum daily air temperature and $T_{\max }$ represents maximum daily air temperature .

$A F I=\sum_{i=1}^{N}\left(\bar{T}_{i}\right)$;

$\overline{T_{i}} \leq 0$

Table1 shows an example of calculation for AFI.

Table1 Example of calculation for AFI.

\begin{tabular}{|l|l|l|l|l|}
\hline Day & Max, ${ }^{\circ} \mathrm{C}$ & Min, ${ }^{\circ} \mathrm{C}$ & Average, ${ }^{\circ} \mathrm{C}$ & $\begin{array}{l}\mathrm{AFI}, \\
{ }^{\circ} \mathrm{C} \text { - Days }\end{array}$ \\
\hline 1 & -1.70 & -17.22 & -9.46 & -9.46 \\
\hline 2 & -12.80 & -23.89 & -18.34 & -27.80 \\
\hline 3 & -12.20 & -22.22 & -17.21 & -45.01 \\
\hline 4 & -9.44 & -18.33 & -13.89 & -58.90 \\
\hline 5 & -1.10 & -8.89 & -4.99 & -63.90 \\
\hline 6 & 3.30 & -1.10 & 1.10 & -62.80 \\
\hline 7 & -1.10 & -7.78 & -4.44 & -67.23 \\
\hline
\end{tabular}

The result of final AFI will be adapted as an absolute value for record. For example, $-67.23{ }^{\circ} \mathrm{C}$-days in Table 1 . will be recorded as $67.23{ }^{\circ} \mathrm{C}$ days for convenience of applications.

Table 2. gives AFI data for Poughkeepsie, New York, USA.

Table 2 AFI data for Poughkeepsie, New York, USA.

\begin{tabular}{|c|c|c|c|c|c|c|c|c|c|c|}
\hline \multicolumn{3}{|c|}{ Description } & \multicolumn{8}{|c|}{ Air Freezing Index Return Periods (OF-Days) \& Associated Probabilities (\%) } \\
\hline $\begin{array}{c}\text { State and Station } \\
\text { Name }\end{array}$ & $\begin{array}{l}\text { Station } \\
\text { Number }\end{array}$ & $\begin{array}{c}\text { Mean Annual } \\
\text { Temp. }\left({ }^{\circ} \mathrm{F}\right)\end{array}$ & $\begin{array}{c}\begin{array}{c}1.1 \text { Year } \\
(10 \%)\end{array} \\
\end{array}$ & $\begin{array}{c}1.2 \text { Year } \\
(20 \%)\end{array}$ & $\begin{array}{l}2 \text { Year } \\
(50 \%)\end{array}$ & $\begin{array}{l}5 \text { Year } \\
(80 \%)\end{array}$ & $\begin{array}{c}10 \text { Year } \\
(90 \%)\end{array}$ & $\begin{array}{c}25 \text { Year } \\
(96 \%)\end{array}$ & $\begin{array}{c}50 \text { Year } \\
(98 \%)\end{array}$ & $\begin{array}{c}100 \text { Year } \\
(99 \%)\end{array}$ \\
\hline $\begin{array}{c}\text { POUGHKEEPSI } \\
\text { E FAAAAP }\end{array}$ & 306820 & 49.1 & 265 & 355 & 554 & 769 & 885 & 1008 & 1088 & 1160 \\
\hline \multicolumn{3}{|c|}{ Description } & \multicolumn{8}{|c|}{ Air Freezing Index Return Periods ( ${ }^{\circ} \mathrm{C}$-Days) \& Associated Probabilities (\%) } \\
\hline $\begin{array}{l}\text { State and Station } \\
\text { Name }\end{array}$ & $\begin{array}{l}\text { Station } \\
\text { Number }\end{array}$ & $\begin{array}{c}\text { Mean Annual } \\
\text { Temp. }\left({ }^{\circ} \mathrm{C}\right)\end{array}$ & $\begin{array}{c}\begin{array}{c}1.1 \text { Year } \\
(10 \%)\end{array} \\
\end{array}$ & $\begin{array}{c}1.2 \text { Year } \\
(20 \%)\end{array}$ & $\begin{array}{l}2 \text { Year } \\
(50 \%)\end{array}$ & $\begin{array}{l}5 \text { Year } \\
(80 \%)\end{array}$ & $\begin{array}{c}10 \text { Year } \\
(90 \%)\end{array}$ & $\begin{array}{c}25 \text { Year } \\
(96 \%)\end{array}$ & $\begin{array}{c}50 \text { Year } \\
(98 \%)\end{array}$ & $\begin{array}{c}100 \text { Year } \\
(99 \%)\end{array}$ \\
\hline $\begin{array}{c}\text { POUGHKEEPSI } \\
\text { E FAAAAP }\end{array}$ & 306820 & 9.5 & 147 & 197 & 308 & 427 & 492 & 560 & 604 & 644 \\
\hline
\end{tabular}

Upper table sourced from National Climatic Data Center(NCDC)

AFI value in lower table was converted from ${ }^{\circ} \mathrm{F}$ into ${ }^{\circ} \mathrm{C}$ by author.

http://www.ncdc.noaa.gov/oa/ncdc.html

According to recommendation by NCDC, only the 100 -year return period in this publication should be used, thus AFI for Poughkeepsie is cited as $644^{\circ} \mathrm{C}$-days. An experimental test rig was built in 2009 in Aomori, Japan and the tests had been carried out for two years during the winter time in 2009 and 2010. Fig. 5 shows the test result from Jan 26 to March 26 in 2010. In that period of time, the AFI was obtained as $56^{\circ} \mathrm{C}$-days following the calculation method shown in Table 1. For a location where the air freezing index AFI is $644^{\circ} \mathrm{C}$-days, the cold energy generated by this module can be estimated via calculation as shown in following discussion.

The average radius of ice column formed around the thermosiphon was $0.125 \mathrm{~m}$ and height of the ice column was $2.6 \mathrm{~m}$ in the test module while thermosiphon pipe outer radius is $0.025 \mathrm{~m}$. The water volume in the tank was about $10 \mathrm{~m}^{3}$, which was measured before ice formed. The average water temperature in the module tank was measured as $0.2{ }^{\circ} \mathrm{C}$.

Figures 6 and 7 show pictures of the experimental rig and the ice that was formed by the module tested. The total cold energy generated by one module will be analyzed as below:

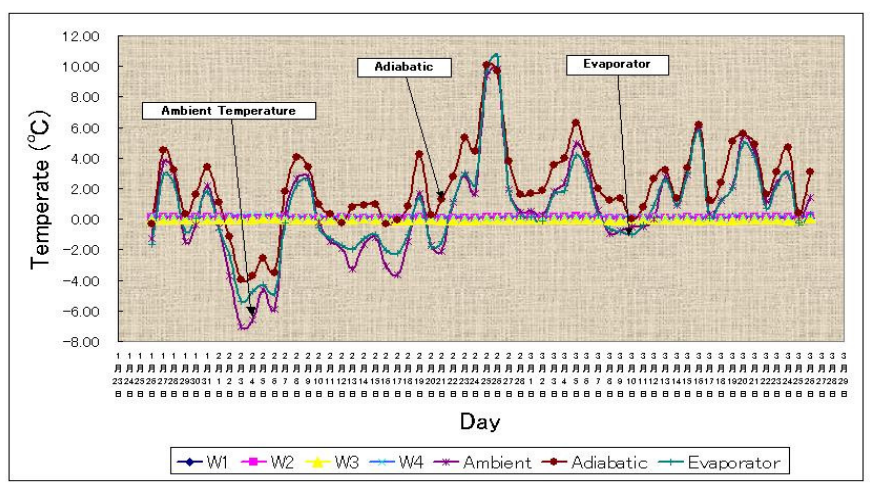

Fig. 5 Freezing and thaw data at Aomori Japan, 2010

Total ice produced

$\mathrm{M}_{\mathrm{ic}}=917 \mathrm{~kg} / \mathrm{m}^{3} \mathrm{x}\left[\pi(0.125 \mathrm{~m})^{2} \times 2.6 \mathrm{~m}\right]-\left[\pi(0.0250 \mathrm{~m})^{2} \times 2.6 \mathrm{~m}\right]$ $=113 \mathrm{Kg}$.

Here $917 \mathrm{~kg} / \mathrm{m} 3$ is density of the ice.

The latent heat of the ice will be

$\mathrm{E}_{\mathrm{lt}}=113 \mathrm{~kg} \times 334 \mathrm{~kJ} / \mathrm{kg}=37.7 \mathrm{MJ}$

Here $334 \mathrm{~kJ} / \mathrm{kg}$ is latent heat of the ice.

For a location with yearly freezing index $644^{\circ} \mathrm{C}$-days, the module can produce latent cold energy per year as

\section{$37.7 \mathrm{MJ}$ x $644{ }^{\circ} \mathrm{C}$-days $/ 56^{\circ} \mathrm{C}$-days $=434 \mathrm{MJ}$.}

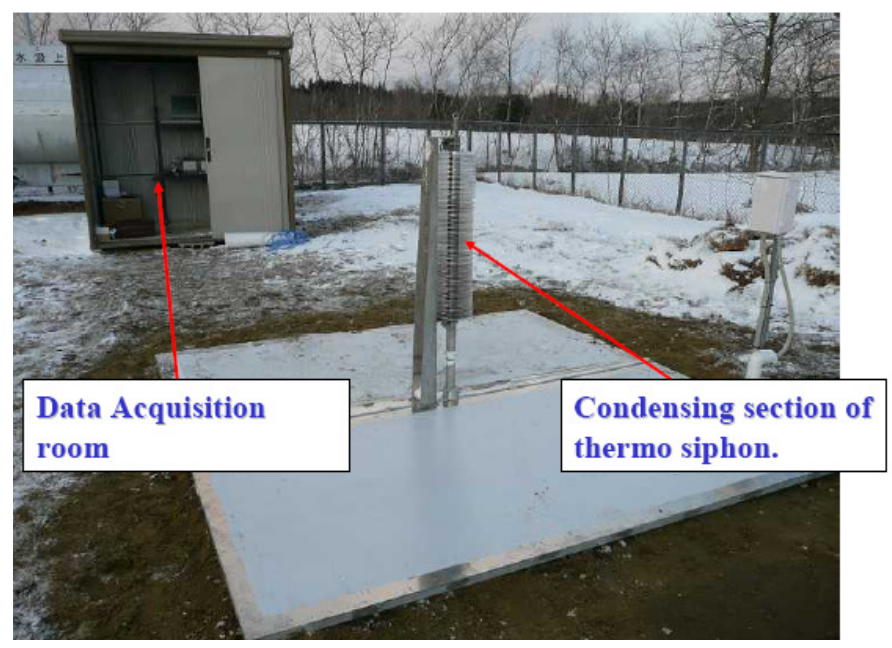

Fig. 6 Test rig of thermosiphon cold energy storage module

As presented in section 5 , the water will be heated up to $25{ }^{\circ} \mathrm{C}$ eventually, the sensible cold energy produced by the module per year will be

$4200 \mathrm{~J} / \mathrm{kg} .{ }^{\circ} \mathrm{C} \times 10 \mathrm{~m}^{3} \times 1000 \mathrm{~kg} / \mathrm{m}^{3} \times\left(25^{\circ} \mathrm{C}-0.2{ }^{\circ} \mathrm{C}\right)$

$=1041 \mathrm{MJ}$.

Here $4200 \mathrm{~J} / \mathrm{kg} .{ }^{\circ} \mathrm{C}$ is specific heat capacity of water and $1000 \mathrm{~kg} / \mathrm{m}^{3}$ is density of water respectively.

Thus total cold energy produced by the single module per year will be $434 \mathrm{MJ}+1041 \mathrm{MJ}=1475 \mathrm{MJ}$. 


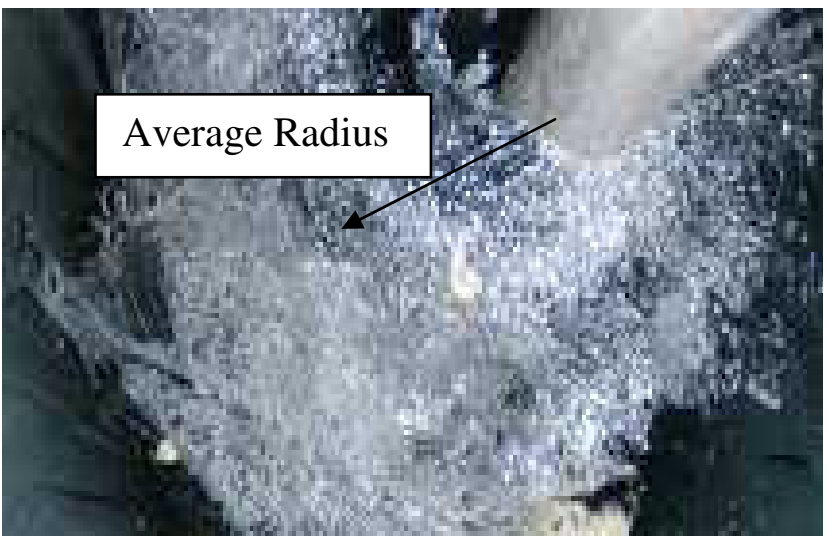

Fig. 7 Ice formed in the thermosiphon module

For $8800 \mathrm{KW}$ heat load, assume $60 \%$ load (it will be further discussed in section 7.) or $5280 \mathrm{KW}\left(1665 \times 10^{5} \mathrm{MJ} / \mathrm{year}\right)$ will be carried out by the thermosiphon modules, the quantity of the modules needed will be 112880 units. For other percentage of heat load taking by thermosiphon the quantity of the modules will vary. Fig. 8 shows thermal net work for how cold water storage system co-operating with chiller system. From the net work, as we can see, heat generated from CPU will be dissipated to the ambient either through heat pipe (thermosiphon) system or can also through chiller system.

For a given heat load, if more load is carried on by the chiller system, there will be less load on thermosiphons.

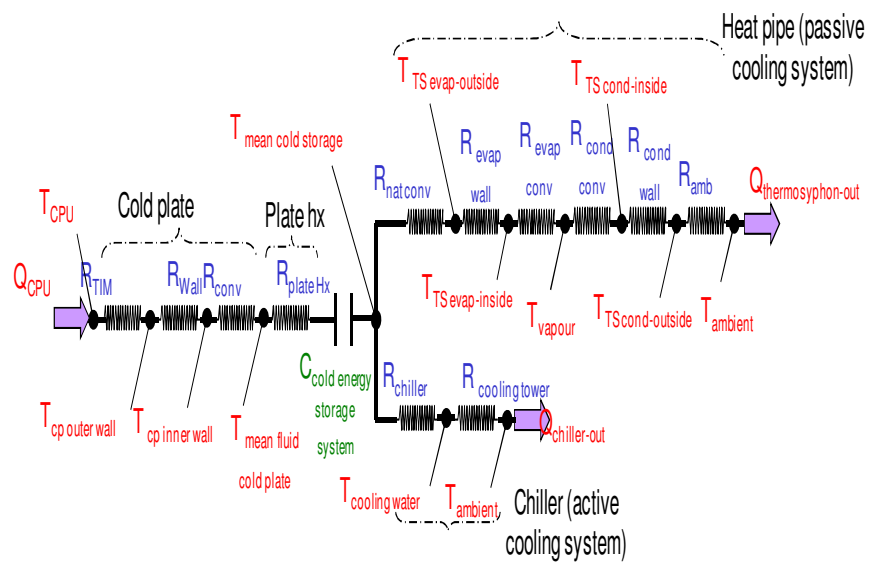

Fig. 8 Thermal net work of the entire cooling system - thermosiphon storage and chiller cooling system

\section{SYSTEM DESIGN AND SIZING}

The cold energy storage design and optimization size should be conducted on the basis of the local metrological conditions. Here take Poughkeepsie, New York for an example. The cold energy storage system is to be sized for a $8800 \mathrm{~kW}$ data center. The yearly temperature/wind data of the place, the number of thermosiphon modules and storage volume required for reducing chiller load by certain percentage will be discussed in this section. In the modeling, the payback time which is used as the factor to optimize the cold energy storage size will be also addressed.

Fig. 9 and 10 present the hourly ambient temperature data in ${ }^{\circ} \mathrm{C}$ and wind speed in $\mathrm{m} / \mathrm{s}$ for Poughkeepsie NY, in the year 2008 respectively which are used to determine the yearly heat transfer rate of the thermosiphon. The location has yearly average temperature of $10{ }^{\circ} \mathrm{C}$ and yearly average wind speed of $1.68 \mathrm{~m} / \mathrm{s}$ as well as the freezing index of approximately $644{ }^{\circ} \mathrm{C}$-days throughout the year.

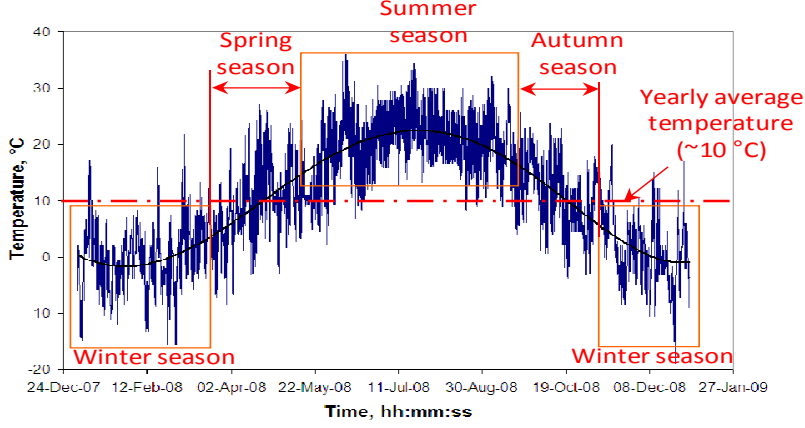

Fig. 9 Hourly temperature variation, Poughkeepsie, NY, 2008

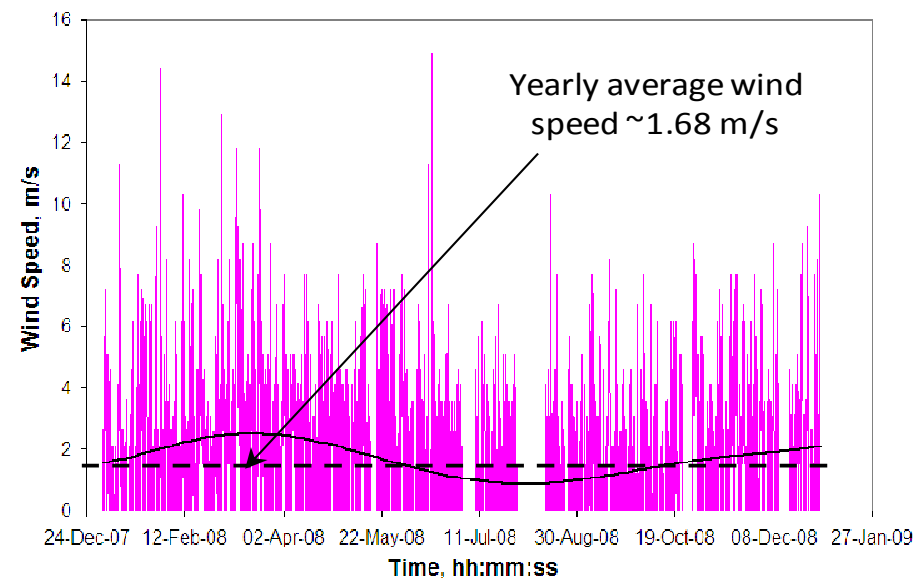

Fig. 10 Hourly wind velocity variation, Poughkeepsie, NY, 2008

Generally speaking, the temperature of the water in the storage will be changing seasonally as shown in Fig. 11. From January to March and October to December, the water temperature is relatively low. $100 \%$ cold storage water can be considered to use for cooling CPU. In this period of the time, the CPU temperature would be varying within an acceptable range $55^{\circ} \mathrm{C}$ to $65^{\circ} \mathrm{C}$ as shown in Fig. 11 . The chiller can also be run in this period of time to help to control the CPU temperature at stable level, but this will not be a point for discussion here in this paper.

As soon as the storage water temperature becomes higher in other warm seasons, the chiller will be run and take more and more cooling load from the storage system till the thermosiphon fully stopped. This would be a gradual process.

In Fig. 11 the lower curve represents storage water temperature variation. The solid line sections of the curve corresponding to the time from January to early April and early October to end of December show water temperature varies from $15^{\circ} \mathrm{C}$ to $25{ }^{\circ} \mathrm{C}$. In this period of time, storage water could handle $100 \%$ cooling load. The size of the storage tank and number of the thermosiphon modules that should be selected to meet this requirement in the thermosiphon storage system design. The dot line in the same lower curve which represents storage water becomes higher than $25{ }^{\circ} \mathrm{C}$ in the warm remaining seasons. In these period of time the thermosiphons will stop working and the chiller should be run.

In Fig. 11 the upper curve represents temperature variation in CPU versus the lower cure (storage). It also shows chiller should be run during the warm seasons. However about 6 months run with the cold storage system that will save significant power. Fig. 12 shows estimated year round load share ratios in percentage between storage system and chiller system. 


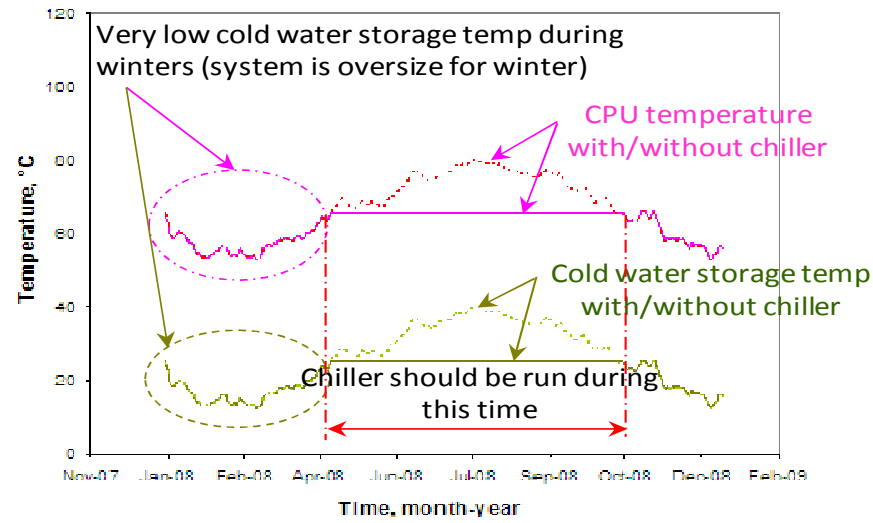

Fig. 11 Yearly variation in the CPU and cold water storage temperatures with and without chiller

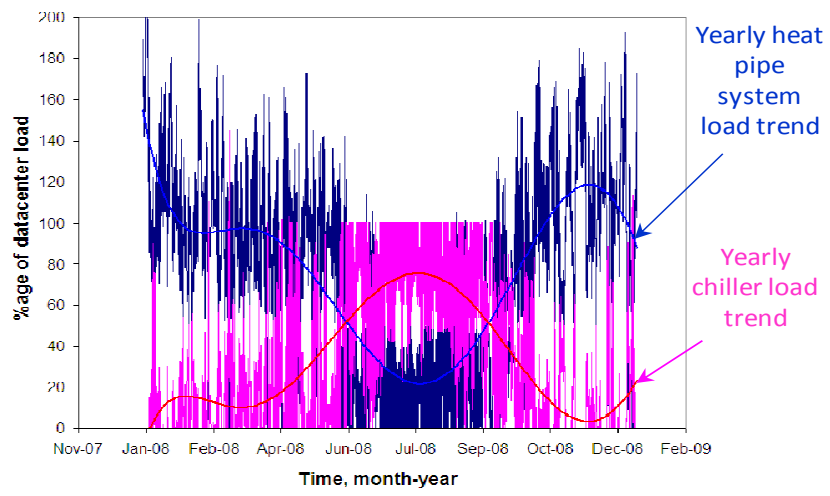

Fig. 12 Percentage of load handled by cold water storage and chiller throughout the year

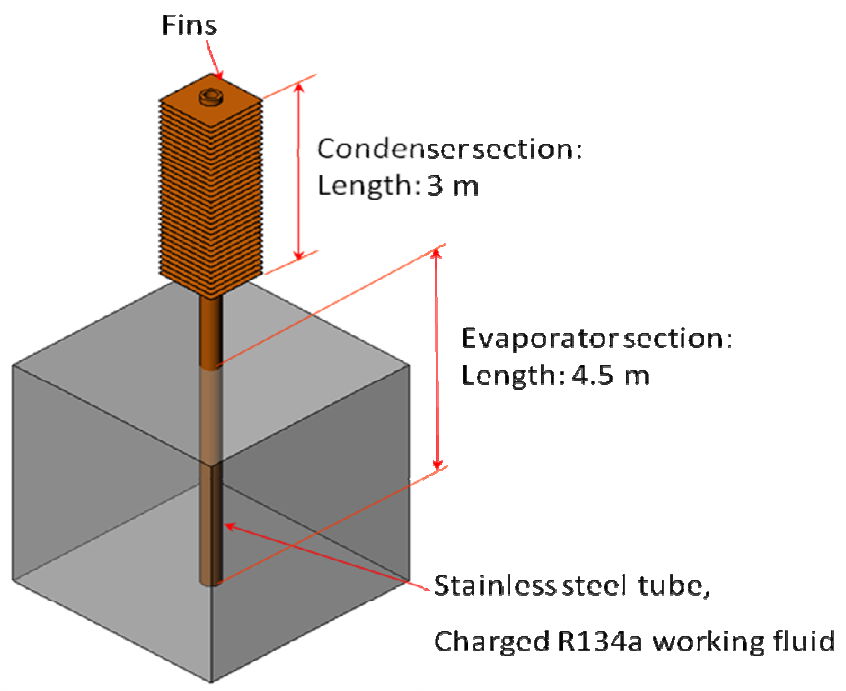

Fig. 13 Enhanced thermosiphon module

The size of the thermosiphon is optimized on the basis of the payback time which is defined as the ratio of the total system cost to the annual savings. It is recognized employing a smaller size of a single module that will be resulting in larger quantity of the units to be required. In another words, the smaller size of thermosiphon the higher cost of unit price will be needed to handle the same load. This will come out that payback time for thermosiphon investment becomes longer. Based on economical analysis, the 112880 units as calculated in section 6 that is over sized in term of cost versus payback. The payback time will be up to 5 years in this size which is not acceptable.
To reduce the payback time, the cooling capability of the single thermosiphon needs to be enhanced by means of increasing the heat transfer areas both on evaporator section and condenser section as well as fins. The computational analysis based on previous modeling and experimental data gives that length of the evaporator section will be increased to $4.5 \mathrm{~mm}$ and condenser length with fins will be increased to $3 \mathrm{~mm}$ as shown in Fig. 13. Consequently, the 112880 units will be reduced to 75288 units.

Following information will give the summary of related economical data. The unit cost of the thermosiphon will be controlled within $\$ 138$ per unit. The storage volumetric space required is estimated as $15 \mathrm{~m}^{3}$ per module which will occupy $3.3 \mathrm{~m}^{2}$ with $4.5 \mathrm{~m}$ depth. The chiller capital cost is constant for $8800 \mathrm{~kW}$ which is counted as $\$ 500$ per $\mathrm{KW}$. In this analysis the chiller is considered that can run at full load rate during peak summer time. And the electricity cost is estimated as $\$ 0.3$ per KWHR.

Fig. 14 plots the cost figures versus payback time for cold water storage system in which. horizontal axle represents the percentage ratio for heat pipe (thermosiphon) storage system sharing the total cooling load. Left hand side vertical axle represents total cost, in million \$, for the entire data center which includes storage system. Right hand side vertical axle represents payback time for the storage system. By the analysis, $60 \%$ total cooling load taking care by cold storage is an optimum ratio. At this ratio, the electricity cost will be saved by approximate 3 million\$/year. And the payback time is about 3.5 years (thermosiphon system cost versus savings). With the reduction of the power consumption about 10.4 kilotons of carbon dioxide will be reduced per year.

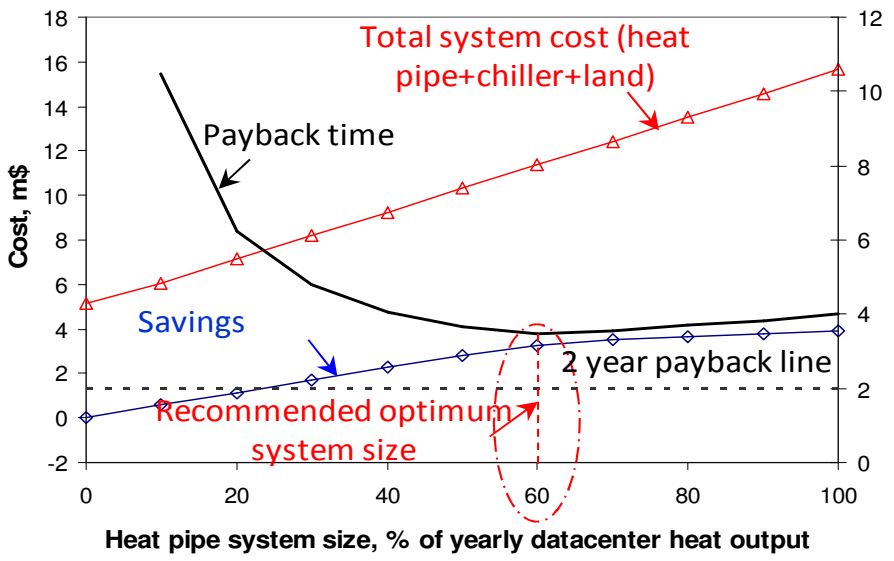

Fig. 14 Total storage system cost versus payback time

\section{OTHER TYPES OF HEAT PIPE BASED COOLING SYSTEM FOR DATA CENTERS}

In this section other types of heat pipe based cooling systems for power consumption saving would be briefly introduced. Fig. 15 shows a heat piped water pre-cooling heat exchanger co-operating with data center.

This system is employing a heat pipe array to act as a pre-cool heat exchanger to reduce the temperature of inlet water before entering the chiller. The cooling capability of the system is about $\sim 5^{\circ} \mathrm{C}$ down after the water going through the system. The energy saving can be estimated as 0.6 million $\$ / y e a r$ for $8800 \mathrm{KW}$ data centers.

Fig. 16 shows a heat piped ice storage system for data center power consumption saving system. This storage will be constructed underground with well insulated. It can be acting as a data center failure support system under an urgent situation when system power shut down. On the other hand, with enough amount of ice generated and stored, it could cool small scale data center year around without chiller. More discussions on heat pipe based pre-cool heat exchanger and ice storage systems will be further addressed in other papers. 


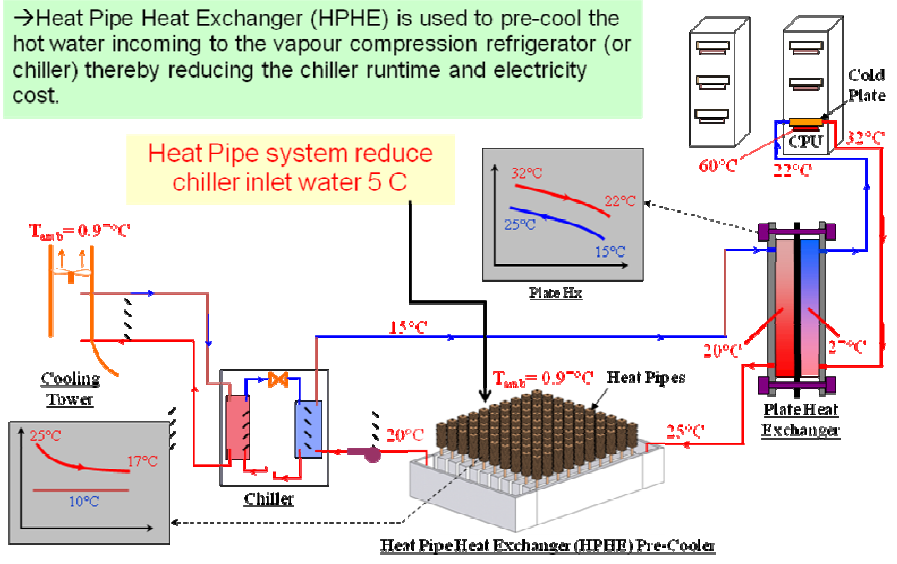

Fig. 15 Heat piped water pre-cooling heat exchanger

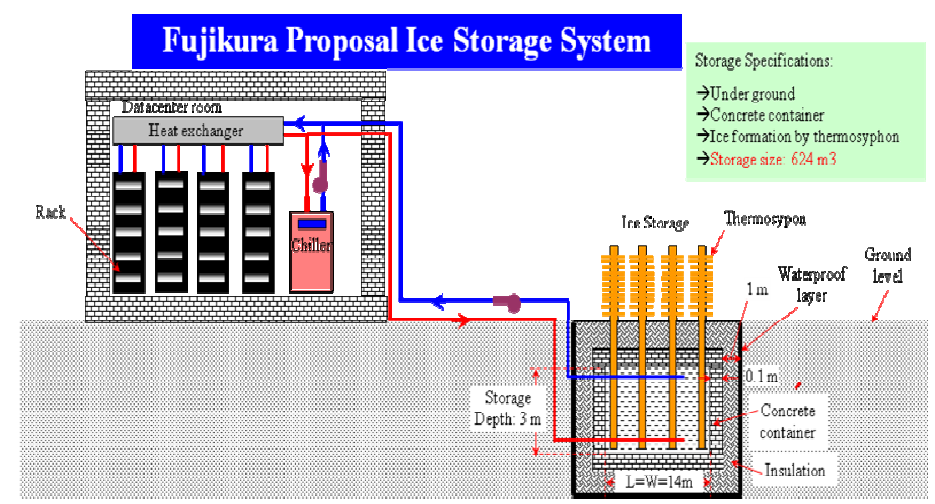

Fig. 16 Heat piped ice storage system

\section{CONCLUSION}

In conclusion, the present paper has proposed the novel concept for thermal management of the data center using heat pipe technology. It can help to minimize the thermal load on the chiller units and thus save electricity as well as reducing green house gas emission. The system can be designed for servicing small and large size data centers. It also can be designed in various types with special functions for particular cooling applications.

However it should be noticed that this type of cold storage is only recommended to be built in the locations where cold seasons can provide sufficient freezing and thawing ambient temperatures. The air freezing index $\mathrm{AFI} \geq 400^{\circ} \mathrm{C}$ - days is strongly recommended.

Future investigations are still needed.

A - area, $\mathrm{m} 2$

\section{NOMENCLATURE}

E - energy, J

$\mathrm{h}$ - overall heat transfer coefficient, $\mathrm{W} / \mathrm{m} 2$. K

$\mathrm{K}$ - thermal conductivity, W/m. K

$\mathrm{L}$ - length, $\mathrm{m}$

$\mathrm{r}$ - radius, $\mathrm{m}$

$\mathrm{R}$ - thermal resistance, ${ }^{\circ} \mathrm{C} / \mathrm{W}$

$\mathrm{M}$ - mass, $\mathrm{kg}$

$\mathrm{T}$ - temperature, ${ }^{\circ} \mathrm{C}$
$\bar{T}$ - mean daily temperature, ${ }^{\circ} \mathrm{C}$

$\varepsilon-$ emissivity

\section{Subscripts}

amb - ambient

$\mathrm{cpu}$ - central processing unit or processor

$\mathrm{cp}$ - cold plate

c - convection, condenser

cod - condenser

conv - convection

cond - conduction

ci - condenser internal

ei - evaporator internal

eo - evaporator external

evap - evaporator

$\mathrm{HX}$ - heat exchanger

ic-ice

lt - latent heat

min - minimum

max - maximum

nat conv - natural convection

$\mathrm{o}$ - evaporator pipe outside

rad - radiation

tl - total

TS - thermosiphon

\section{REFERENCES}

Kenneth G. Brill, 2006, "2005 - 2010 Heat Density Trends in Data Processing, Computer Systems, and Telecommunications Equipment: Perspectives, Implications and the Current reality in Many Data Centers," 2000 - 2006 The Uptime Institute, version 2.1.

Moore, J., Sharma, R., Shih, R., Chase, J., Patel, C., and Ranganathan, P., 2004, "Going beyond CPUs: The potential for temperature-aware data centers," Proceedings of the First Workshop on TemperatureAware Computer Systems.

Patel C.D., Sharma R., Bash C.E., 2002, "Beitelmal A., Thermal Considerartions in Cooling Large Scale High Compute Density Data Centers," Proceedings of 2002 Inter Society Conference on Thermal Phenomena, IEEE.

Schmidt R., Iyengar M., Steffes J., Lund V., 2009, "Co-generationGrid Independent Power and Cooling for a Data Center," Proceedings of the ASME 2009 InterPACK Conference.

Schmidt R.R., Crus E.E., Lyengar M.K., 2005, "Challenges of Data Center Thermal Management,” IBM J Res \& Dev., Vol. 49, No. 4/5, July-September 2005.

Singh, R., Akbarzadeh, A., Mochizuki, M., 2009, "Effect of Wick Characteristics on the Thermal Performance of the Miniature Loop Heat Pipe," Journal of Heat Transfer, Volume 131, No. 8, 082601. doi: $10.1115 / 1.3109994$

Zhang, Y., Faghri, A., and Shafii, M. B., 2002, "Analysis of LiquidVapor Pulsating Flow in an U-Shaped Miniature Tube," International Journal of Heat and Mass Transfer, Vol. 45, No. 12, pp. 2501-2508. doi: 10.1016/S0017-9310(01)00348-9 